\title{
A rare case of congenital facial nerve palsy with extreme ocular manifestations
}

\author{
Rahul Kumar Bafna (D) ', Suman Lata (D) ,' Anusha Sachan (D) , \\ Mohamed Ibrahime Asif (i) ${ }^{2}$
}

${ }^{1}$ Ophthalmology, All India Institute of Medical Sciences, New Delhi, India

${ }^{2}$ Opthalmology, Rajendra Prasad Center for Ophthalmic Sciences, Delhi, Delhi, India

\section{Correspondence to}

Dr Suman Lata;

suman.dhanda300@gmail.com

Accepted 27 April 2021

\section{DESCRIPTION}

A 12-month-old malnourished female child, born by normal vaginal delivery, presented to us with lagophthalmos and healed corneal ulcer with keratinisation. Examination revealed right facial asymmetry, temporal hollowing, loss of nasolabial fold and drooping of the right angle of mouth (figure 1C) with lagophthalmos, ptosis with grade 6 exposure keratopathy of right eye (figure $1 \mathrm{~A}, \mathrm{~B}$ - side view, $1 \mathrm{~d}$ front view). A clinical diagnosis of congenital facial nerve palsy with exposure keratopathy was made. In addition to facial nerve palsy, there was laryngomalacia resulting in protein energy malnutrition. On paediatric evaluation, no other cranial nerve or other organ abnormalities were seen. Lateral tarsorrhaphy was done and planned for penetrating keratoplasty

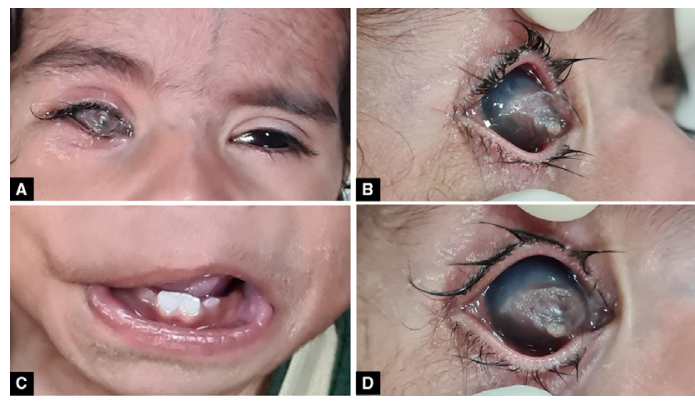

Figure 1 (A) Shows right facial asymmetry, temporal hollowing, lagophthalmos with healed keratitis. (B) A side view of the right eye showing grade 6 exposure keratopathy involving central and inferior cornea. (C) Shows loss of right side nasolabial fold and drooping of the right angle of mouth. (D) A front view of the right eye showing grade 6 exposure keratopathy involving central and inferior cornea.

\section{Patient's perspective}

We, the parents of child (12 months old child) are very disturbed with the condition of our only child. We have been explained about the nature of disease and the outcomes of intervention (tarsorrhaphy). We are a bit relieved after understanding the when and why it happened to our child and are hopeful about the improvement in eye status and look forward to future intervention in terms of optical penetrating keratoplasty for visual rehabilitation. subsequently. ${ }^{1}$ We highlight the need for early ocular examination and regular follow-up in these cases to avoid blinding sequelae. Congenital facial nerve palsy and musculoskeletal abnormalities can be associated with Moebius, ${ }^{2}$ Poland, ${ }^{3}$ Goldenhar ${ }^{4}$ and $\mathrm{CATCH}_{-}$ $22^{5}$ syndromes, and needs a careful evaluation for same.

\section{Learning points}

- Congenital facial nerve palsy needs early diagnosis and regular follow-up to look for recovery and for development of any ocular complications.

- Congenital facial nerve palsy and musculoskeletal abnormalities can be associated with Moebius, Poland, Goldenhar or CATCH-22 syndrome, and needs careful evaluation.

Twitter Anusha Sachan @Anusha Sachan

Contributors Dr RKB: Conception and design. Dr SL: Planning and reporting: Dr AS: Acquisition of data. Dr MIA: Data analysis and review of literature.

Funding The authors have not declared a specific grant for this research from any funding agency in the public, commercial or not-for-profit sectors.

Disclaimer Case reports provide a valuable learning resource for the scientific community and can indicate areas of interest for future research. They should not be used in isolation to guide treatment choices or public health policy.

Competing interests None declared.

Patient consent for publication Obtained.

Provenance and peer review Not commissioned; externally peer reviewed.

\section{ORCID iDs}

Rahul Kumar Bafna http://orcid.org/0000-0002-6795-0508

Suman Lata http://orcid.org/0000-0002-2218-3130

Anusha Sachan http://orcid.org/0000-0001-9737-6706

Mohamed Ibrahime Asif http://orcid.org/0000-0002-9949-3962

\section{REFERENCES}

1 Lee V, Currie Z, Collin JRO. Ophthalmic management of facial nerve palsy. Eye 2004;18:1225-34.

2 Sweeney PJ, Hanson MR, Bradley WG. The cranial neuropathie. In: Neurology in clinical practice. , 1991: II, 1556-7.

3 Mace JW, Kaplan JM, Schanberger JE, et al. Poland's syndrome. Report of seven cases and review of the literature. Clin Pediatr 1972:11:98-102.

4 Baraitser M, Winter RM, Rennie JM. Textbook of neonatology. 875 3rd ed, 1999

5 Ehara H, Hara T, Takeshita K. Catch 22: a possible cause of congenital unilateral facial nerve palsy. Eur J Pediatr 1997:156:739. 
Images in...

Copyright 2021 BMJ Publishing Group. All rights reserved. For permission to reuse any of this content visit https://www.bmj.com/company/products-services/rights-and-licensing/permissions/

BMJ Case Report Fellows may re-use this article for personal use and teaching without any further permission.

Become a Fellow of BMJ Case Reports today and you can:

- Submit as many cases as you like

- Enjoy fast sympathetic peer review and rapid publication of accepted articles

Access all the published articles

Re-use any of the published material for personal use and teaching without further permission

Customer Service

If you have any further queries about your subscription, please contact our customer services team on +44 (0) 2071111105 or via email at support@bmj.com.

Visit casereports.bmj.com for more articles like this and to become a Fellow 